\title{
A RECRIAÇÃO DA REALIDADE PELO DISCURSO PUBLICITÁRIO
}

\author{
Reconstruction of reality by advertising speech
}

\author{
Renata Corrêa Coutinho
}

Publicitária, Especialista em Comunicação e Marketing, Mestre em Comunicação, professora do Curso de Publicidade e Propaganda do Centro Universitário Católico Salesiano Auxilium de Araçatuba/SP, da Fundação Educacional do Município de Assis e da Faculdade do Norte Pioneiro do Paraná, Assis, SP - Brasil, e-mail: renatacorreacoutinho@gmail.com

\section{Resumo}

Este artigo apresenta a contextualização histórico-social do surgimento das mensagens publicitárias, bem como destaca o processo evolutivo dos argumentos comunicativos - o racional e o emocional - e sua correlação aos estágios de desenvolvimento da sociedade capitalista brasileira, o que faz surgir o argumento ético-social. Tratada como um espelho da sociedade, a publicidade pode ser entendida como um gênero narrativo que carrega em sua composição elementos extraídos do contexto em que foi concebida, pois seu objetivo é o de buscar o estabelecimento de identificação com o público a que se dirige, a fim de que esse a perceba como um intensificador de atitudes, esperanças e sonhos que povoam o seu imaginário pessoal.

Palavras-chave: Discurso publicitário. Mensagem publicitária. Responsabilidade social empresarial. Argumento ético-social.

\begin{abstract}
This article presents the historical and social context of the emergence of advertisement messages, and also highlights the evolutionary process of the communicative arguments - the rational and the emotional - and its correlation to the development stages of capitalist society in Brazil, which gives rise to the social-ethical argument. Seen as a reflection of the society, advertising can be understood as a narrative genre that carries in its composition elements extracted from the context in which it was conceived, since its goal is to seek the identification with the public to whom it is directed, in order to be viewed by the public as an intensifier of attitude, hope and dreams that populate their imaginary universe.
\end{abstract}

Keywords: Advertisement speech. Advertisement. Corporate social responsibility. Social-ethical argument. 


\section{APRESENTAÇÃO}

Embora seja possível encontrar inúmeras tentativas de periodização do nascimento da propaganda, sabe-se que ela é um acontecimento recente. $\mathrm{O}$ contexto atrelado ao surgimento da comunicação comercial, tão presente em nosso cotidiano, é o da rápida transição de uma sociedade tradicional e fortemente campesina - na qual a ênfase estava na execução de trabalhos manuais -, para uma moderna sociedade de massas e suas inovações tecnológicas, tais como a mecanização do trabalho e a invenção de novas técnicas de comunicação.

No século XVIII, a automação nos diversos setores da indústria sofre impulso notável com o aparecimento da máquina a vapor, aumentando significativamente a produção.

É nesse ambiente que o homem descobre uma forma industrial de produção, relegando a partir de então ao segundo plano a "ultrapassada" forma manual: do artesanato passa-se, subitamente, à produção realizada pelas máquinas, à substituição da energia muscular pela energia elétrica e mecânica, já que permitiam produzir em larga escala com grande economia de mão de obra.

Entre os inúmeros frutos advindos da força industrial está a superprodução, que trouxe uma infinidade de bens "indispensáveis" à felicidade humana, preenchendo as necessidades materiais - denominadas fisiológicas e de segurança, de acordo com a Teoria de Maslow - e sociais aquelas que correspondem ao afeto, status, estima e realização, segundo a mesma teoria. "O ponto crucial é que, ao consumir bens, estamos satisfazendo ao mesmo tempo necessidades materiais e sociais" (VESTERGAARD; SCHRODER, 2000, p. 5).

A partir dessa nova referência de vida, muito mais consumista, se faz necessário o desenvolvimento de algumas atividades atreladas à produção, dentre as quais a publicidade e a propaganda.

\section{PUBLICIDADE E PROPAGANDA: a serviço do capitalismo}

A propaganda passa a representar uma ferramenta a serviço das várias ideologias, sobretudo daquelas defendidas pelos detentores dos meios de comunicação, os quais a utilizavam, desde o princípio, como amplificadora de seus interesses ideológicos, políticos e comerciais.

[...] Do ponto de vista estrutural, ela [a publicidade] surgiu como braço informativo do sistema econômico em que se inseria [o capitalismo], num tempo em que as cidades cresciam e as populações começavam a passar de centenas de milhares. A vida urbana se sofisticava em opções e as pessoas deixavam de se conhecer pelo nome e sobrenome. Contar aos outros transformou-se em comunicar alguma coisa ao mercado (MARCONDES, 2002, p. 15).

Destarte, o capitalismo alastra-se como sistema e modo de vida "infinitamente melhor" a tudo quanto já havia sido experimentado pelas pessoas-o "padrão universal de desenvolvimento" para Bauman (2001, p. 20) - e seus diversos preceitos passam a sinalizar padrões a serem perseguidos a qualquer custo. Desde então, os bens produzidos tornam-se, pouco a pouco, indispensáveis à sobrevivência de qualquer ser mortal.

$\mathrm{E}$ as mensagens de propaganda passam a atuar como dinamizadoras do uso dos produtos inicialmente, e mais adiante dos valores e formas de vida subjacentes a eles, sempre refletindo o contexto histórico-social em que estão inseridas.

À guisa desses fatos, pode-se, então, situar o aparecimento de ambas - propaganda e publicidade como são compreendidas no presente -, a partir do advento da produção em massa: propaganda e publicidade como instrumentos capazes de exercer influência sobre o grande contingente citadino, apresentando-lhe uma nova ideia de mundo - $\mathrm{o}$ american way of life ${ }^{1}-\mathrm{e}$

\footnotetext{
1 Os Estados Unidos viveram uma grande recessão econômica entre as décadas de 1920 e 1930: superprodução e falta de mercado comprador para muitas das mercadorias. O modo americano de vida, promovido pelo governo com o uso da propaganda, contribuiu para a superação da crise e a criação do maior mercado consumidor do mundo.
} 
os novos produtos recém-saídos das fábricas que sintetizavam essa cosmovisão peculiar.

Inicialmente intitulados reclames (do francês reklame), os primeiros anúncios não tinham a pretensão de convencer/persuadir o consumidor, mas tão somente o de comunicar às pessoas a existência de determinados objetos e serviços, tais como: escravos, propriedades rurais e urbanas, leilões e aulas particulares (PINHO, 1990).

Esses anúncios eram essencialmente informativos e buscavam apresentar fundamentalmente a localização-referência geográfica do local-de onde era possível encontrar tais produtos. Nas palavras de Marcondes (2002, p. 15), "a propaganda nasceu prestando serviços, na forma que poderíamos chamar de primórdios dos classificados modernos".

Gradativamente, um novo rol de serviços e produtos começa a ser inserido no conjunto de artigos já anunciados - lojas, hotéis, remédios e mercadorias importadas - e com a inclusão deles, o uso de ilustrações de artistas plásticos do período, poesias e textos de autores conhecidos, configurando os primeiros contatos entre a publicidade e a arte.

Embora muitos autores prefiram apresentar os conceitos de publicidade e propaganda de modo delimitável, no Brasil já se convencionou a utilização de ambos os termos indistintamente, até mesmo porque há confluência de significado; porém, o termo "propaganda" é empregado genericamente, pois possui significado mais amplo.

Mesmo não havendo completa equivalência entre elas, a questão mostra-se apenas como um problema de nomenclatura, o qual não é o objetivo deste trabalho dirimir. Portanto, não faremos uso inflexível dos termos publicidade e propaganda.

É certo que ao assumir os contornos explicitamente comerciais, a propaganda explora o universo do prazer, dos sonhos e das fantasias daquele público que pretende atingir a fim de "vender" um produto ou serviço, exprimindo também um ideário de valores e comportamentos.

Ambas, publicidade e propaganda, estão baseadas na recriação da realidade e aí reside sua característica mimética; nelas, acontecimentos são relatados por personagens que performatizam condutas e comportamentos humanos que visam a promover a identificação virtual do receptor, podendo ou não culminar na aquisição de um dado produto ou serviço ou na adesão das ideias pré-formuladas.
[...] de acordo com o entendimento comum e até com os dicionários, propagar também é disseminar uma comunicação, uma idéia, um argumento. Ação essa que pode ser parte de uma atividade de venda. Vendem-se tanto mercadorias como idéias, ao se propagarem suas qualidades e características. (PREDEBON, 2004, p. 18).

Na publicidade, a persuasão verbal manifesta-se a partir de uma somatória entre "os recursos lingüísticos e a exploração das representações socialmente incorporadas pelos indivíduos [os esquemas estereotipados]" (CITELLI, 1995, p. 46); pode-se dar em presença de construções originais e instigantes que propõem uma direção oposta à habitualmente esperada - mecanismo de estranhamento -, do uso sistemático de efeitos retóricos como as figuras de linguagem, as técnicas argumentativas e o raciocínio formal [silogismo]-premissa maior, premissa menor e conclusão.

[...] na realidade, a linguagem publicitária usa recursos estilísticos e argumentativos da linguagem cotidiana, ela própria voltada para informar e manipular. Falar é argumentar, é tentar impor. O mesmo se pode dizer da linguagem jornalística, dos discursos políticos (sobretudo em época eleitoral), da linguagem dos tribunais (defesas e acusações apaixonadas) a até do discurso amoroso. Em todos esses casos, há uma base informativa que, manipulada, serve aos objetivos do emissor. A diferença está no grau de consciência quanto aos recursos utilizados para o convencimento e, nesse sentido, a linguagem publicitária se caracteriza pela utilização racional de tais instrumentos para mudar (ou conservar) a opinião do público-alvo. (CARVALHO, 2003, p. 9).

O discurso narrativo - utilizado com astúcia e profissionalismo a fim de causar efeitos de sentido, quer sejam eles reais, sublimes ou emocionais manifesta-se não apenas nas telenovelas, na literatura ou no jornalismo, mas permeia inúmeros tipos de mensagem em todos os meios de comunicação, já que homens e mulheres vivem narrativamente o seu mundo, construindo temporalmente suas experiências (MOTTA, 2004, p. 20-21). 
No anúncio publicitário é possível constatálo não somente nos textos verbais, pois

[...] a foto publicitária procura realçar aspectos da vida das pessoas, de como elas são e como deveriam ser, procuram remeter a imaginação para as vidas individuais, para as histórias e biografias de cada um, criando desejos a partir de imaginários pessoais. Mesmo quando há uma única foto [...] há história em volta, há história sugerida. (MOT'TA, 2004, p. 21).

Independentemente do objeto que propaga, quer ele de natureza comercial e/ou ideológica, é certo que a publicidade e a propaganda são capazes de espelhar o contexto em que foram concebidas, pois propõem a manutenção das normas já instituídas ao refletir as atitudes, esperanças e sonhos dos receptores o mais fielmente possível (VESTERGAARD; SCHRODER, 2000, p. 133).

\section{UM ESPELHO DA SOCIEDADE: a argumentatividade racional e emocional na publicidade}

A publicidade como manifestação e expressão natural da atividade mercantil de um povo contém elementos, implícitos ou explícitos, extraídos das relações sociais diversas desempenhadas na sociedade e dos vários sistemas que a alimentam, tais como os sistemas de crenças, os valores artísticos, científicos, educacionais, sociais, políticos e econômicos.

O gênero publicitário é imediatamente reconhecido pelos participantes de uma comunidade, pois assume características de

um discurso matizado pela cultura em que está inserido, um discurso que utiliza a língua da comunidade e escolhe o léxico mais aceito e a carga lexical que lhe é inerente - assim como a imagem, produto e produtor da cultura (CARVALHO, 2003, p. 105).
Assim, a publicidade encerra não apenas o contexto no qual foi desenvolvida, mas sobretudo os valores e comportamentos tidos como aceitáveis e/ ou desejáveis nessa mesma comunidade. Carvalho (2003, p. 106) salienta que a comunicação publicitária induz a uma visão dinâmica do social por privilegiar as idéias mais atuais, os fatos em emergência, as inovações tecnológicas, as correntes de última hora. Em suas palavras,

O texto publicitário, qualquer que seja a mensagem implícita,é o testemunho de uma sociedade de consumo e conduz a uma representação da cultura a que pertence, permitindo estabelecer uma relação pessoal com a realidade particular. Sua mensagem primeira e explícita é o estímulo ao consumo de um produto, mas ele põe em destaque determinado aspecto de uma cultura, como um projetor poderoso [...].

A publicidade não tem por objetivo contradizer a ordem já estabelecida na sociedade, não cabe a ela o papel de inquirir e questionar a realidade tal como ela se apresenta; ao contrário, a publicidade se aproxima da realidade dos receptores, buscando retratar características próprias da vida das pessoas com a finalidade de estabelecer alguma identificação (TOALDO, 2000, p. 71).

Ou seja, um anúncio manterá sua representatividade de apelo comercial, todavia se revelará uma textura significativa composta por textos verbais e não-verbais que transportam referências culturais, sociais e ideológicas de um dado povo.

Pringle e Thompson (2004) apresentam uma tríade que bem sintetiza as fases trilhadas pelas mensagens publicitárias ao longo das últimas décadas e, consequentemente, os apelos por elas utilizados: o argumento racional, o argumento emocional e o argumento ético-social, também conhecido como espiritual, os quais refletem respectivamente o espírito de cada época ${ }^{2}$.

Embora o fim último de toda organização empresarial sempre tenha permanecido o mesmo,

\footnotetext{
2 Para este trabalho, utilizaremos as denominações de argumento racional e emocional. Optaremos ainda pelo uso do termo éticosocial, em detrimento do espiritual, pois esse nos parece exprimir com mais completude aquilo que é por natureza seu objeto de composição: a ética e a sociedade.
} 
ou seja, a obtenção do lucro, atingir esse objetivo ao longo dos tempos implicou a mudança das orientações seguidas pelas empresas e uma consequente readequação da linguagem adotada por elas.

Inicialmente, com a demanda superior à oferta, as empresas mostravam-se unicamente orientadas para a produção (1920-1930); vislumbravam, a partir do uso de tecnologia, a redução dos custos - uma vez que esses atuavam como elemento que impedia a expansão do mercado - e o aumento da quantidade produzida, o que, consequentemente, deveria resultar na fabricação de produtos a preços baixos.

Logo, as mensagens publicitárias esmeravam-se apenas por ressaltar as características físicas das matérias produzidas, bem como para explicitar dados informativos acerca do uso e de sua disponibilidade no mercado; a utilização do argumento racional ocorria exclusivamente para a demonstração dos atributos do produto, já que a concorrência ainda poderia ser considerada inexpressiva e a finalidade do produto era comumente desconhecida pela massa em geral.

$\mathrm{Na}$ construção desses anúncios - estritamente racionais - se dava prioritariamente o enfoque ao produto a partir de uma linguagem essencialmente objetiva e informativa, com predomínio da função referencial - centrada no referente: o produto.

Ainda empregada em nossos dias, a objetividade argumentativa - ou argumento racional depende da existência de uma mensagem honesta a comunicar e mostra-se mais eficaz quando o destinatário está disposto a comprar e a buscar ativamente por uma informação técnica, objetiva e, portanto, mensurável.

Quando se trata das bases racionais da mensagem, as quais utilizam-se apenas do campo cognitivo para garantir sua eficiência, isto é, alcançar o receptor, tal recurso visa atingir o plano da consciência do receptor da mensagem. Assim, ele pode compará-la com a informação disponível e verificar se ela lhe é ou não importante. Neste caso, utiliza-se uma informação objetiva, garantindo a veracidade do que é informado (BOCK, 1999, p. 279).

Senos anos 20 era possível vender mercadorias que apelassem à estrita funcionalidade do produto, buscando a satisfação física do consumidor de maneira racional, esse já não era mais o modo suficientemente adequado de portar-se frente a ele, no período posterior (1930-1950). A oferta muito superior à demanda instaurou uma conjuntura que converteria as vendas e a comunicação em instrumentos potencializadores da ação pretendida - o consumo.

Essa tornou-se uma fase conhecida como de orientação para as vendas, já que as empresas passaram então a dedicar maior importância ao papel desempenhado pelo vendedor, já que seria ele o responsável direto - auxiliado pela propaganda - pelo escoar do excesso de mercadorias.

Particularmente neste período, a tendência é acreditar que o consumidor possa ser induzido a comprar um produto graças à ação de estímulo e persuasão exercitada pela organização de venda. É o período em que se afirmam as atividades publicitárias e promocionais, com a convicção de que as mesmas sejam capazes de persuadir e dirigir o consumidor (DI NALLO, 1999, p. 36).

Os anos seguintes revelaram-se muito mais competitivos, e assim as empresas passaram a buscar alternativas de sobrevivência. Convencer apenas pela racionalidade já não mais funcionava, pois a existência de uma avalanche de produtos praticamente indistinguíveis tornava necessário o uso de novas formas de convencimento, e assim o argumento emocional passa a significar a via possível de estabelecer uma comunicação com o público pretendido ao apelar à subjetividade inerente ao ser humano.

[...] é possível e freqüente a utilização de recursos de base irracional (de fundo emotivo), que são associados ao conteúdo cognitivo da mensagem. Tal forma de convencimento tenta persuadir o receptor da mensagem mais pelo campo da subjetividade do que pelo da objetividade da informação. [...] A técnica mais comum é a de associar um determinado valor social ao produto anunciado (BOCK, 1999, p. 280).

A construção desses anúncios começa a se dar a partir de outro referente: o consumidor. A linguagem empregada passa a enfatizar a ação do produto sobre quem o consome a partir da utilização das funções emotiva (centrada nos sentimentos, na subjetividade) e apelativa (baseada na conação, isto é, no exercício da influência sobre o 
próximo), explicitamente demonstrada pelo uso do verbo imperativo.

Elementos persuasivos e sedutores passam a integrar as mensagens mais corriqueiramente, dentre os quais se nota a inserção da imagem de personalidades para endossar o uso dos produtos anunciados.

Essa "nova era", centrada no ser humano, nos seus desejos, necessidades e expectativas acaba por inaugurar uma visão do processo administrativo totalmente inovadora e de estreita ligação com a propaganda e o mundo empresarial: a transição do eixo focal da empresa que resulta na descentralização do produto e na entronização do consumidor como sendo o verdadeiro sentido de existência de qualquer negócio.

Tida como uma verdadeira evolução da relação empresa-mercado, a fase de orientação para o mercado (a partir de 1950) assenta-se sobre o consumidor como o centro referente de toda e qualquer idealização de produto, e as pesquisas tornam-se o ponto de partida para o desenvolvimento das soluções desejadas pelo soberano-consumidor.

Assim o enfoque não mais se restringe somente à troca econômica, mas especialmente às trocas simbólicas (DI NALLO, 1999, p. 31), as quais serão amplamente explicitadas pela propaganda.

A orientação do mercado é, naturalmente, o húmus necessário ao nascimento do marketing. [...] O marketingé, ao menos na fase inicial de sua existência, uma função específica da empresa, dirigida à individualização das necessidades do consumidor e a agir para satisfazê-las. E é uma função que tende a se tornar dominante quando a empresa é orientada para o mercado, ou seja, dirige suas forças não para uma maior ou melhor produtividade, nem para persuadir os consumidores, mas sobretudo para a satisfação dos mesmos. [...] Efetivamente, a era do marketing moderno nasce quando algumas entre as principais empresas dos Estados Unidos se direcionam para o mercado e para a compreensão e a satisfação das necessidades do consumidor (DI NALLO, 1999, p. 36-37).

Surgida num contexto industrial como "disciplina empresarial dedicada à colocação dos bens no mercado com o máximo de lucro" (DI NALLO, 1999, p. 27) e com o objetivo de fazer com que esse segmento se beneficiasse através de uma interpretação até então não convencional - de fora para dentro, do consumidor para a empresa -, a "doutrina" de marketing amplia-se no pós-guerra, e com ela a aplicação de suas estratégias e de seus métodos.

O conceito de marketing é uma orientação direcional que considera como papel principal da empresa (ou de qualquer outra entidade) descobrir necessidades, carências e valores de um mercado-objetivo, e adaptar-se para satisfazê-los de forma mais eficaz e eficiente que seus concorrentes (DI NALLO, 1999, p. 41).

Invocando a satisfação do consumidor, o argumento emocional se constrói a partir de valores extraídos do próprio universo do público que se pretende atingir.

Se as pessoas preocupam-se basicamente consigo mesmas, então é compreensível que as comunicações sejam mais atraentes a elas se forem diretamente relevantes a suas próprias circunstâncias, a seu comportamento de compra e às aspirações de estilos de vida (PRINGLE; THOMPSON, 2004, p. 70-71).

Esses elementos de composição emocionais, presentes sobretudo na narrativa publicitária, apresentam-se como uma possibilidade de fuga inconsciente frente a tantas regularidades, regras e repetições do cotidiano.

Enquanto o dia a dia é povoado por centenas de restrições de ordem moral, cultural e advindas da desigualdade econômica, tornando irrealizáveis os prazeres edênicos, "a publicidade apresenta-nos, intensa e continuamente, a oferta do paraíso e da ascensão social" (BOCK, 1999, p. 281).

E essa tem sido a tônica ainda predominante nas mensagens publicitárias: aquela que consiste na exaltação contundente das virtudes, comumente individualistas, obtidas mediante o consumo de uma infinidade de paramentos capazes de conduzir reles mortais ao tão almejado paraíso particular.

Conquanto os apelos emocionais pareçam prevalecer, sobretudo nas propagandas de produtos e serviços, nota-se uma preocupação com o aspecto informativo, por meio do uso de argumentos racionais que buscam estabelecer uma relação real e de maior proximidade com o receptor, na medida em que se apresentam as possibilidades tangíveis de aquisição 
do produto, bem como as características funcionais e estruturais do material ofertado.

O fato é que esses dois enfoques - racional e emocional -, em vez de serem abolidos da mensagem publicitária, são atualmente utilizados em um mesmo anúncio, conjuntamente ou em separado, dependendo do objetivo pretendido pela mensagem.

Todavia, se por um lado experimentamse grandes possibilidades de comunicação e contato por meio do reconhecimento explícito do universo dos receptores - quer pelas mensagens, quer pelos artefatos recém-saídos do mundo capitalista -, por outro lado, os frutos dessa propalada modernidade se traduzem cada vez mais no estabelecimento de prioridades acentuadamente negativas, tal qual o indivíduo em detrimento da sociedade e os desejos particulares em detrimento das necessidades coletivas.

Para Bauman (2001), as pessoas foram impelidas a desejar a individualidade como sinônimo de liberdade e acabam por se mostrar frágeis e impotentes isoladamente enquanto que o ato de "ir às compras" é tido como um "ritual de exorcismo dos temores que assolam o 'dono do corpo' obcecado com níveis inalcançáveis de aptidão, devolvendo, ainda que instantaneamente, a promessa de segurança”. Por esse motivo, o indivíduo é cada vez mais impulsionado pela noção do desejo de consumo como se sua autoexpressão pudesse ser demonstrada através de suas posses.

Zygmunt Bauman assinala ainda que uma das facetas da individualização parece ser a corrosão e a lenta desintegração da cidadania e que,

[...] a individualização é uma fatalidade, não uma escolha. [Pois] $\mathrm{Na}$ terra da liberdade individual de escolher, a opção de escapar à individualização e de se recusar a participar do jogo da individualização está decididamente fora da jogada. [...] se [os indivíduos] ficam doentes, supõe-se que foi porque não foram suficientemente decididos e industriosos para seguir os tratamentos; se ficam desempregados, foi porque não aprenderam a passar por uma entrevista, ou porque não se esforçaram o suficiente para encontrar trabalho ou porque são, pura e simplesmente, avessos ao trabalho; se não estão seguros sobre as perspectivas de carreira e se agoniam sobre o futuro, é porque não são suficientemente bons em fazer amigos e influenciar pessoas e deixaram de aprender e dominar, como se deveriam, as artes da autoexpressão e da impressão que causam. Isto é, em todo caso, o que lhes é dito hoje, e aquilo em que passaram a acreditar, de modo que agora se comportam como se essa fosse a verdade (BAUMAN, 2001, p. 43).

\section{QUESTÕES CONTEMPORÂNEAS: o bem-estar social como foco comunicativo na propaganda}

É sabido que há muito o trabalho voluntário e a filantropia estão presentes na sociedade. Contudo, os últimos anos têm revelado maior visibilidade a essas práticas, em virtude da irrestrita constatação da impossibilidade, creditada por muitos exclusivamente ao Estado, em exterminar a gritante desigualdade de oportunidade entre as classes.

A própria dinâmica social é responsável pela produção da violência ao mesmo tempo em que produz também a ideia de comunidade e família - como num organismo que, ao apresentar distúrbio em uma de suas partes, reage através de seus dispositivos de defesa a fim de expelir/neutralizar a anomalia detectada -, fato que requer do Estado a contribuição no sentido de minimizar as dificuldades, pois esse deve atuar como mecanismo regulador dos sistemas político-social, na administração da organização societária.

Maffesoli (1996, p. 73-74) destaca que:

a sociedade não é apenas um sistema mecânico de relações econômico-políticas ou sociais, mas um conjunto de relações interativas, feito de afetos, emoções, sensações que constituem, stricto sensu, o corpo social. Um conjunto encarnado de certo modo, repousando sobre um movimento irreprimível de atrações e de repulsões. [...] [em que] observa-se um desejo de estar-junto que, sendo não-consciente, não deixa de ser poderoso. [...] a natureza, na sua unicidade, é um efeito de composição entre a razão e a paixão, e que é essa conjunção que preside às relações humanas.

Diante desse abismo social, cada vez mais intransponível, uma força agregativa desperta em meio ao individualismo triunfante e um elevado 
número de cidadãos têm optado por dedicar parte de seu tempo disponível à realização de alguma atividade em prol do próximo.

Nas palavras de Maffesoli (1996, p. 37) presenciamos o "deslize de uma lógica de identidade [essencialmente individualista] para uma lógica da identificaşão [muito mais coletiva]".

O engajamento da sociedade civil a partir de suas percepções éticas e suas respectivas preocupações para com a coletividade refletem-se também nas atuais ações empreendidas pelo chamado mundo corporativo.

A tentativa de cicatrização das chagas do corpo social pode ser notada na manifestação de dois movimentos, que podemos julgar complementares. De um lado, as iniciativas do Terceiro Setor ${ }^{3}$, por meio das entidades não governamentais, do voluntariado, da defesa dos direitos humanos e do consumidor; e de outro a mobilização do setor empresarial, ao pôr em prática a cidadania corporativa, que implica a

relação socialmente responsável da empresa em todas as suas ações, em todas as suas políticas, em todas as suas práticas, em todas as suas relações. Isso significa responsabilidade social da empresa em relação à comunidade, aos seus empregados, aos seus fornecedores, aos fornecedores de seus fornecedores, aos fornecedores dos fornecedores dos seus fornecedores, ao meio ambiente, ao governo, ao poder público, aos consumidores, ao mercado, aos acionistas. Quando nos propomos a abarcar todas essas relações, estamos nos referindo à forma da gestão empresarial (GRAJEW, 2000, p. 44).

Toda a sociedade reúne-se com o objetivo de buscar formas possíveis de resolutividade da problemática socioeconômica e de seus variados desdobramentos na área educacional, ambiental e cultural.

Para Oded Grajew ${ }^{4}$ (2002 apud MADUREIRA, 2002, p. 36), a responsabilidade social demonstra ser um processo irreversível e um importante diferencial para as empresas, embora existam opiniões divergentes sobre o assunto: há aqueles que pensam ser esse um modismo, outros acreditam que é mais uma forma para "enfeitar" a imagem das empresas; todavia, há quem acredite que se trata de um movimento importante para o destino de toda a humanidade.

Nesse sentido, o setor empresarial é muito poderoso em termos de mobilização, pois possui recursos financeiros, econômicos, informação, mídia e poder político, fatores que geram grande impacto na agenda da sociedade.

A partir desses questionamentos sociais e do alvorecer de um possível processo evolucional humanitário, novas terminologias para a atividade de marketing vão surgindo, preservando-se o objetivo primordial, que é o de satisfazer as necessidades e desejos de um determinado target - a fim de tornar e/ou manter um negócio lucrativo -, somando-se a uma visão mais responsável do aspecto social.

Esse novo enfoque corresponde exatamente à proposta de Marketing para Causas Sociais (PRINGLE; THOMPSON, 2004), uma vez que pretende cativar os consumidores, a partir da demonstração de engajamento da empresa na sociedade, uma demonstração que se fará cada vez mais visível a partir do argumento ético-social empregado na construção das mensagens publicitárias.

A associação entre marcas e causas sociais tem aparecido com frequência nos diversos veículos de comunicação. Essa alternativa mercadológica é viável para a empresa patrocinadora do projeto e benéfica a determinados grupos da sociedade, já que pode lhes propiciar o acesso à informação.

Dentre as inúmeras iniciativas promovidas e divulgadas, citamos, a título de ilustração, o Criança Esperança (Rede Globo de Televisão, em parceria com a Unesco), Fundação O Boticário e Fundação Natura (ambas atuam em favor da proteção à natureza), Concurso Talentos da Maturidade (Banco Real) e McDia Feliz (McDonald's).

Pringle e Thompson (2004, p. 3) asseveram que "a adoção de uma 'causa' pode dar a uma marca um 'credo' ou 'sistema de crenças' e isso pode

3 O Terceiro Setor é denominado social, ou seja, o das organizações sem fins lucrativos que têm como função a modificação de vidas. O Primeiro Setor é composto pelas organizações governamentais, governo e empresas estatais, e o Segundo Setor é o privado, o qual congrega as empresas privadas com fins lucrativos, reunindo indústria, comércio e serviços (LINS, 2000, p. 38).

4 Oded Grajew é presidente e fundador do Instituto Ethos de Empresas e Responsabilidade Social, criado (em junho de 1998, no Brasil) para disseminar a prática da responsabilidade social empresarial. 
resultar numa percepção e intenção de compra significativamente melhor, por parte do consumidor". Uma via de mão dupla que garante um diferencial competitivo à empresa, que explora mercadologicamente o feito e permite o acesso da população - ou parte dela - a áreas e atividades antes restritas aos grupos mais abastados.

Pringle e Thompson (2004, p. 3) apontam sinteticamente a definição do que elas denominam de Marketing para Causas Sociais como "uma ferramenta estratégica de marketing e de posicionamento que associa uma empresa ou marca a uma questão ou causa social relevante, em benefício mútuo".

Entretanto, que fique claro, marketing [para causa] social não é sinônimo de filantropia, mas uma estratégia de negócios que tem o objetivo de criar uma imagem positiva da empresa para seus clientes internos e externos, acionistas, comunidade em que se encontra inserida e fornecedores através de ações sociais/ambientais que trazem benefícios para a sociedade (ZENONE, 2006, p. 73).

Verifica-se que tal prática tem sido uma forma inegável das empresas contribuírem tanto para a melhoria das condições de vida da população na qual está inserida, quanto para uma perspicaz estratégia de manutenção e perpetuação da marca que representam.

É plenamente coerente, portanto, acreditarmos que haja um elevado grau de consciência por parte das empresas privadas em relação às dificuldades da população e do país e que muitas delas estejam se esmerando na tentativa de minimizar as desproporcionalidades sociais existentes.

Todavia, deve-se considerar a via capitalista sob a qual a sociedade está constituída; via essa que nos possibilita apreender a nítida intenção mercadológica inerente ao fenômeno: as empresas não empreendem atividades e projetos que priorizam o social por caridade, mas para a obtenção de algum retorno (ZENONE, 2006, p. 106). Nesse panorama, a propaganda - como atividade estreitamente ligada às empresas e, consequentemente, ao marketing também vai ganhando novos contornos.

Atualmente, nota-se nas propagandas, sobretudo naquelas que divulgam a imagem institucional das organizações, uma ênfase exacerbada na divulgação de atividades e projetos dirigidos ao bem-estar social. Fato esse que Pringle e Thompson (2004) assinalam como sendo o surgimento de um novo argumento denominado ético-social (ou espiritual), o qual, segundo as autoras, inaugura os anos 1990 como a década humanitária.

Esse argumento tem, sumariamente, por finalidade demonstrar a contribuição de dada empresa para com a sociedade por meio da realização de projetos ligados às questões culturais, ambientais, educacionais, profissionais, dentre outras preocupações sociais.

Resultado de uma culpa coletiva ocasionada pela riqueza material conquistada em detrimento de um sentimento de falta de realização pessoal uma marca característica do fim da década de 80 (PRINGLE, 2004, p. 78), o argumento ético-social vem refletir as inquietações do ser humano da sociedade contemporânea.

Com explícito objetivo ético-social, essas mensagens não clamam em favor do produto em si ou da própria marca explicitamente, tampouco em favor dos desejos individuais do consumidor-alvo, mas das necessidades do próximo ou da sociedade.

Imbuídas de extrema generosidade e senso crítico a respeito das mazelas sociais vividas pela população desfavorecida, as propagandas construídas a partir do argumento ético-social revelam os atos hercúleos empreendidos pelas organizações na tentativa de minimizar a exclusão social, facilitando o acesso às mais elementares necessidades humanas, como a alimentação, a educação e a recuperação da auto-estima.

\section{CONSIDERAÇÕES FINAIS}

Partindo da premissa de que "os seres humanos têm uma predisposição cultural primitiva e inata para organizar e para compreender a realidade de modo narrativo (MOTTA, 2004, p. 7)", pensamos que a leitura da propaganda como construção narrativa faz sentido na medida em que nela constam elementos textuais e imagéticos capazes de fornecer informações sobre um dado assunto e seu contexto.

Assim, notamos que as empresas passam a conduzir suas atividades de maneira socialmente engajada, pois é esse o "espírito do tempo" (MAFFESOLI, 1996), o procedimento valorizado pela sociedade e possivelmente uma forma de atrair a simpatia do consumidor. 
E que seguindo essa mesma dinâmica também está a propaganda, que abandona, em certa medida, o enfoque no produto (abordagem racional) e a ênfase no indivíduo (abordagem emocional) para inaugurar uma visão centrada na sociedade e em suas problemáticas sociais, a partir do uso do argumento ético-social.

\section{REFERÊNCIAS}

BAUMAN, Z. Modernidade líquida. Rio de Janeiro: Jorge Zahar, 2001.

BOCK, A. M. B. Psicologias: uma introdução ao estudo de psicologia. São Paulo: Saraiva, 1999.

CARVALHO, N. Publicidade: a linguagem da sedução. São Paulo: Ática, 2003.

CITELLI, A. Linguagem e persuasão. São Paulo: Ática, 1995.

DI NALLO, E. Meeting points. São Paulo: Marcos Cobra, 1999.

GRAJEW, O. O que é responsabilidade social. Mercado Global, ano 27, n. 107, p. 44-50, 2000.

LINS, J. P. O terceiro setor profissionalizado distribui dividendos para toda a sociedade. Mercado Global, ano 27, n. 107, p. 38-43, 2000.

MADUREIRA, D. Responsabilidade social: questão de sobrevivência. Caderno Especial, ano 24, n. 1.005, p. 36-39, 2002.

MAFFESOLI, M. No fundo das aparências. Petrópolis: Vozes, 1996.
MARCONDES, P. Uma história da propaganda brasileira. Rio de Janeiro: Ediouro, 2002.

MOTTA, L. G. Narratologia: análise da narrativa jornalística. Brasília: Casa das Musas, 2004.

PINHO, J. B. Propaganda institucional: usos e funções da propaganda em relações públicas. São Paulo: Summus, 1990.

PREDEBON, J. Curso de propaganda: do anúncio à comunicação integrada. São Paulo: Atlas, 2004.

PRINGLE, H.; THOMPSON, M. Marketing social: marketing para causas sociais e a construção das marcas. São Paulo: Makron Books, 2004.

TOALDO, M. M. Ética, moral e publicidade. Mercado Global, ano 27, n. 107, p. 70-81, 2000.

VESTERGAARD, T.; SCHRODER, K. A linguagem da propaganda. São Paulo: Martins Fontes, 2000.

ZENONE, L. C. Marketing social. São Paulo: Thomson Learning, 2006.
Recebido: 01/09/2009

Received: 09/01/2009

Aprovado: 28/09/2009

Approved: 09/28/2009

Revisado: 11/01/2009

Reviewed: 01/11/2009 